\title{
Formation of Environmentally Friendly Tourist Behaviors in Ecotourism Destinations in China
}

\author{
Jie Ren, Kaiwen Su, Yaoyin Chang and Yali Wen *
}

Citation: Ren, J.; Su, K.; Chang, Y.; Wen, Y. Formation of Environmentally Friendly Tourist Behaviors in Ecotourism Destinations in China. Forests 2021, 12, 424. https://doi.org/10.3390/f12040424

Academic Editor: Rebecca Jordan

Received: 6 February 2021

Accepted: 30 March 2021

Published: 1 April 2021

Publisher's Note: MDPI stays neutral with regard to jurisdictional claims in published maps and institutional affiliations.

Copyright: (c) 2021 by the authors. Licensee MDPI, Basel, Switzerland. This article is an open access article distributed under the terms and conditions of the Creative Commons Attribution (CC BY) license (https:// creativecommons.org/licenses/by/ $4.0 /)$.
School of Economics and Management, Beijing Forestry University, 35 Qinghua East Road, Beijing 100083, China; renjie@bjfu.edu.cn (J.R.); sukaiwen@bjfu.edu.cn (K.S.); changyaoyin@bjfu.edu.cn (Y.C.)

* Correspondence: wenyali@bjfu.edu.cn

\begin{abstract}
The rapid development of ecotourism provides a win-win path for ecological and environmental protection and sustainable economic development. However, environmental problems are increasingly prominent in ecotourism destinations, which seriously hinders their sustainable development. This study explored how environmental knowledge, environmental perceived value, perceived consumption effectiveness, and environmental attitudes stimulate and shape environmentally friendly tourist behaviors. A sample survey of 406 tourists at Taibai Mountain National Nature Reserve in China was conducted, and structural equation modeling (SEM) was used to assess the causal relationships in the formation of environmentally friendly behaviors. The results show that environmental knowledge has a significant positive impact on environmental attitudes, environmental perceived value, and perceived consumption effectiveness. Further, environmental perceived value has a significant positive impact on environmental attitudes and environmentally friendly behavior; environmental attitudes and environmental behavior have a significant positive impact; environmental awareness has a significant positive impact on environmental behaviors; and perceived consumption effectiveness has a significant positive impact on environmentally friendly behaviors and is the most important direct predictor. Overall, the results reveal the formation mechanism of environmental friendly behavior, and provide a scientific basis and theoretical support for the stimulation and shaping of environmentally friendly tourist behaviors in ecotourism destinations.
\end{abstract}

Keywords: ecotourism; environmentally friendly behavior; perceived consumption effectiveness; environmental knowledge; structural equation modeling

\section{Introduction}

The concept of ecotourism was formally proposed in the 1980s as a sustainable ecological practice. Since then, ecotourism has developed rapidly and is becoming one of the fastest-growing forms of tourism, with an annual global growth rate of $5 \%$. Ecotourism was initially used to refer to all forms of tourism based on the ecological environment and natural resources [1], including natural experiences and landscape appreciation [2]. In addition, the behaviors in the process of ecotourism must be environmentally sustainable and eco-friendly [3], requiring environmental responsibility to be borne in mind by all participants $[4,5]$. Meanwhile, ecotourism has an educational role, which can shape people's environmental awareness, attitudes, and behaviors and, where effective, can help reduce environmental damage. Furthermore, ecotourism offers attractive opportunities for profit generation in line with current moral norms; tourists can engage with the natural environment in a pleasing and sustainable way, and tourism operators can secure profitable revenues. Based on these perspectives, ecotourism is not only a tool for protecting the environment, but is also a development path that can deliver win-win results.

Traditional tourism is one of the major driving forces promoting social and economic development. However, excessive development and utilization have negative effects on the natural environment, leading to a series of environmental problems [6]. Given that ecotourism is founded on both ecological and economic gains, economic benefits cannot 
be sought at the expense of the environment, including any potential damaging impacts of tourists. In practice, the assumed potential of ecotourism has not been fully realized, positive relationships between tourist behaviors and environmental protection can be difficult to establish [7]. On the one hand, the pressure of excessive commercial development poses a significant environmental threat to ecotourism destinations and has a non-negligible impact on carbon emissions from transportation, catering, shopping, and other consumer activities. On the other hand, tourist behaviors also interfere with the ecological environment, whether intentionally or unconsciously (e.g., disturbing wild animals, collecting flowers or wild vegetables, and noise pollution). For example, in recent years, some ecotourism destinations have suffered unexpected degradation due to the excessive consumption of natural services and ecological products [8], including negative tourist impacts on the environment and biodiversity protection [9]. Especially for the protected areas with fragile ecosystem and low degree of development, the destruction of ecotourism with poor planning and irregular behavior of tourists is devastating [10,11]. Some protected areas regard ecotourism as a panacea to coordinate community development and ecological protection [12,13], but improper ecotourism may bring a series of problems. For example, the degradation of water systems [14], deforestation leads to the decline of forest coverage and the quality of forest land $[15,16]$, the destruction of wildlife habitat leads to the reduction of biodiversity $[17,18]$. Therefore, stimulating environmentally friendly tourist behavior has an important role to play in the environmental protection of ecotourism destinations.

In the field of tourism research, environmentally friendly behavior can be defined as behavior that causes the least damage to or is beneficial for the environment, either directly or indirectly. Such behaviors are affected by internal and external factors and can be intervened and guided by effective measures [19]. It is widely recognized that the sustainable development of ecotourism largely depends on the behaviors of tourists; as consumers of tourism services, tourists participate in and can influence the entire ecotourism development process. Indeed, environmental cognition, willingness to engage in sustainable activities, decision-making in tourism activities, and individual behavior have a strong influence on the direction of ecotourism development. In response to this, significant research progress has been made on the factors influencing tourist environmentally friendly behaviors, focusing on environmental knowledge, environmental attitudes, beliefs, loyalty, responsibility, and attraction; green purchasing behavior, and local attachment [20-22]. Understanding those factors that influence and stimulate environmentally friendly behaviors can, therefore, provide valuable theoretical support for establishing best practices and suitable guidelines for tourists and destination managers.

To better understand the formation of environmentally friendly behaviors in ecotourism areas, this paper describes an empirical study employing a structural equation model (SEM) to evaluate the causal relationships between environmental knowledge, environmental attitudes, environmental perceived value, perceived consumption effectiveness, and environmentally friendly behaviors in 406 Chinese tourists. The research focuses on evaluating how perceived consumption effectiveness shapes environmental attitudes and behaviors of tourists to inform interventions aimed at reducing the environmental damage in ecotourism areas. In doing so, this study makes the following contributions: (1) A structural equation method is used to evaluate the formation of environmentally friendly tourist behaviors and build a theoretical basis for these behaviors; (2) given the diversity of environmental protection strategies in China encompassing strict protection, ecological utilization (including ecotourism), and parallel protection and rational utilization, this study provides valuable insights for nature reserves strictly managed for biodiversity conservation alongside small-scale ecotourism. This focus is important given the potential diversity of the attitudes and behaviors of tourists visiting different types of tourism destinations [23]; and (3) the discussed findings provide valuable information for ecotourism destination managers, offering a scientific basis for stimulating environmentally 
friendly tourist behaviors and the development of effective and sustainable ecotourism management strategies.

\section{Theoretical Background and Research Hypotheses}

\subsection{Environmental Knowledge}

The concept of environmental knowledge originated from environmental psychology, denoting the ways in which the environment can be recognized by individuals and organizations. Such "knowledge" is composed of the objective information about and attention given to an environment or ecosystem owned by individuals or organizations, and the impact of human behavior on it. This includes factual knowledge about the structure and function of ecosystems [24], as well as the strategies and abilities to solve environmental problems [25]. More recently, environmental knowledge has been taken to encompass the impacts and causes of environmental problems, as well as the actions taken to address the relationships between people and the environment [26].

It is widely considered that richer environmental knowledge stimulates an individual's sense of responsibility to protect the environment [27-29]. If people have a poor understanding of environmental problems and the measures required to respond, they may not pay attention or take actions to address them. Similarly, the more people know about the environment and related issues, the more likely they are to show concern [30]. Therefore, environmental management goals can be addressed by managing people's environmental knowledge, which has significant effects on environmental beliefs, sensitivities, and attitudes [31-34]. For example, Barr [35] analyzed the factors influencing the environmental attitudes and behaviors of farmers in the UK, finding that an increase in environmental knowledge stimulated positive environmental attitudes. Similarly, in China, Fan et al. [36] examined environmentally friendly tourist behaviors in the Dongjiang Lake and found that prior environmental knowledge had a significant positive impact on environmental attitudes. This was also found to be the case for urban residents in China [37]. Based on this, hypothesis H1a states that environmental knowledge has a significant positive impact on environmental attitudes.

As a subjective cognition, the perceived value of ecotourism experiences is influenced by the scope and degree of object cognition [38]. Ecotourists have travel behavior based on the values they place on ecological environment services, and their own environmental knowledge leads to environmental protection psychology and their individual value judgments [39]. Therefore, tourist environmental knowledges affect the perceived benefits and utility of ecotourism experiences alongside individual value judgments. In general, the more environmental knowledge tourists have, the stronger the perceived value of the ecotourism experiences they engage in. Thus, H1b states that environmental knowledge has a significant positive impact on environmental perceived value.

Perceived consumption effectiveness aims to measure people's awareness of their ability to change the environment through their own behaviors. This depends not only on environmental knowledge, but also their direct and indirect prior experience as well as level of education [40]. Based on planned behavior theory, perceived consumption effectiveness plays an indirect role in predicting behavior [41], and the causal relationship between objective knowledge and behavior can also be mediated by perceived consumption effectiveness. Therefore, environmental knowledge not only affects emotional preferences for the ecological environment, but also an individual's confidence in solving environmental problems and, ultimately, their actions taken [42]. Thus, H1c states that environmental knowledge has a significant positive impact on perceived consumption effectiveness.

\subsection{Environmental Perceived Value}

Perceived value is a form of subjective judgment defined as the comparison of perceived giving and receiving [43]. In the context of tourism, environment perceived value reflects the perceptions and judgments of tourists with respect to the transaction between tourism costs (i.e., time, money, and effort) and benefits (i.e., services and products) [44]. 
Stevens [45] stated that the perceived value of the environment is founded in tourists' evaluations of the products and services purchased at the destination, and Murphy [46] suggested that value can be regarded as a combination of the utility and the corresponding price obtained by recreation. Tourists synthesize this combination to form an environmental perceived value. Thus, environment perceived value is defined here as the subjective evaluation of the total utility obtained by tourists after weighing up the perceived benefits and cost of obtaining tourism products or services. The following five dimensions are typically considered - either individually or in combination — in research on environmental perceived value: Service value, functional value, environmental value, emotional value, and cost value [38,47-49].

Attitude, as the acquired emotional tendency of cognitive subjects, also has subjective initiative and is influenced by existing information and past experience. Therefore, the perceived value of the environment can change a subject's attitude toward the environment. For example, Ruiz-Molina et al. [50] conducted an empirical analysis on the relationships among consumer perceived value, attitude, and loyalty, and they found that consumer perceived value has a significant positive impact on attitude. Huang and Shih's [29] research also shows that tourists with higher perceived value are more willing to protect the destination being visited. Furthermore, residents with higher perceived value also have significantly improved environmental attitudes [51,52]. Thus, H2a states that environmental perceived value has a significant positive impact on environmental attitudes.

The relationship between environmental perceived value and behavior has been widely discussed, with higher environmental perceived value typically associated with environmentally friendly behaviors [53-56]. For example, Eggert and Ulaga [57] showed that rather than paying attention to the costs of tourism, tourists pay more attention to whether they can gain a good tourism experience. Further, if tourists believe that tourism can bring more positive effects to environmental protection, they will be more motivated to protect the environment. Chiu $\mathrm{Y}$ et al. [53] found that perceived value, ecotourism activity involvement, and satisfaction all have important effects on tourist pro-environmental behavior. Thus, $\mathrm{H} 2 \mathrm{~b}$ states that tourist environment perceived value has a significant positive impact on environmentally friendly behavior.

\subsection{Perceived Consumption Effectiveness}

The belief that one's own action can greatly alleviate environmental problems varies between individuals. The perception of consumption effectiveness was proposed in the 1970s as the subjective judgment of people in their ability to affect the outcome of things [58]. This is important because an individual's evaluation of his or her ability to change something determines the likelihood that he or she will take action [59]. Thus, in general, when tourists believe that their environmental attitudes and behaviors can change the current environmental situation, including reducing environmental deterioration and ecological imbalance, perceived consumption effectiveness is produced. This can be measured as a predictor of environmental problems [58]. For example, Straughan and Roberts [60] applied perceived consumption effectiveness as one means of predicting environment-related behaviors, finding it was a better predictor than environmental attitude. Consequently, environmental attitude and perceived consumption effectiveness are considered to be two different research entities in this study [42], although they are often strongly correlated [61]. Overall, if an individual believes that environmental problems can be solved through specific activities, this will strongly affect their willingness to participate in such actions $[62,63]$. Therefore, H3a states that perceived consumption effectiveness has a significant positive impact on environmental attitude.

According to the theory of planned behavior, perceived consumption effectiveness plays an indirect role in predicting many behaviors [41], including perceived behavior control, subjective norms, and environmentally friendly behaviors [64], reflecting the perceived subjective behavior ability of individuals participating in environmental behavior [65]. It is also believed that the perceived effectiveness of consumers has strong explanatory power 
against green consumption behavior; the stronger the perceived effectiveness of consumers, the stronger the belief that their behavior will change the status quo, and the more likely they are to adopt green consumption behaviors [66,67]. Melnyk et al. [68] also emphasized that consumer beliefs about behavioral outcomes directly affect green purchase intentions and influence consumer choice. Thus, $\mathrm{H} 3 \mathrm{~b}$ states that perceived consumption effectiveness has a significant positive impact on environmentally friendly behavior.

\subsection{Environmental Attitude}

Environmental attitude is a collection of an individual's beliefs, emotions, behavioral intentions, and psychological tendency toward environment-related activities [69], typically expressed by a certain degree of love or disgust [70]. Environmental attitude has a potential impact on people's behavior, and consequently received much research attention. Many studies have found that a positive attitude toward environmental protection can lead to environmentally friendly behaviors by tourists [71-73].

Currently, many theoretical frameworks have been proposed to explain the relationships between environmental attitudes and environmentally friendly behaviors, such as rational behavior theory, planned behavior theory, and value-belief-normative theory. According to these theories, environmental attitude is one of the decisive factors in determining an individual's motivation to participate in positive environmental behaviors [74-76]. Indeed, Kang et al. [77] found that environmentally friendly behaviors are the product of environmental attitudes. In their study of tourists on the Gold Coast of Australia, Perkins et al. [78] found that a strong environmental attitude was a significant predictor of environmentally friendly behaviors. Thus, $\mathrm{H} 4$ states that environmental attitude has a significant positive impact on environmentally friendly behavior.

\subsection{Environmentally Friendly Behaviors}

The concept of "environmentally friendly behaviors" originates from the field of environmental sociology, born in America in the 1960s [79]. Since then, due to the increasing concern about environmental problems, research on environmental behavior has become increasingly notable. More specifically, environmental behavior is regarded as the intentional behaviors of individuals or groups that directly or indirectly affect or benefit the environment and promote the protection and sustainable utilization of resources. Hines and Hungerford [80] first proposed the notion of "responsible environmental behavior" as a type of a subjective initiative whose purpose is to prevent occurrence of environmental problems or improve the environment, the starting point of which is individuals' environmental attitude and sense of environmental responsibility. Cottrell and Graefe [81] believed that environmentally friendly behaviors reflect individuals' environmental knowledge, attitudes, and beliefs, as they manifest in a range of behaviors [77,82-84]. These behaviors can have a positive impact on the effective use of natural resources and, therefore, alter the structure and dynamic cycling of ecosystems and the biosphere [85]. Qi et al. [86] defined environmentally friendly behavior as "individual action [and] active participation to solve or prevent ecological problems" in their study of the relationship between tourist environmental attitudes and environmental behaviors at natural heritage sites in China; Zhao et al. [87] defined environmentally friendly behavior as the initiative to protect the environment or solve ecological problems; Fan et al. [52] included tourist actions in favor of the sustainable development of a tourism destination in their definition; and Fan et al. [36] also refer to the environmental protective behaviors of individuals. Furthermore, definitions of environmental behavior encompass an entire range of activities including beneficial environmental behavior, responsible environmental behavior, environmentally sensitive behavior, pro-environmental behavior, green consumption behavior, ecologically oriented behavior, ecologically friendly behavior, and environmentally sustainable behavior [88].

In this paper, in the specific context of ecotourism, the term "positive environmental behavior" is applied to represent environmentally friendly behaviors in which tourists take 
the initiative to minimize the negative impacts of their behavior on the environment or support the sustainable development of an ecotourism destination.

To sum up, the purpose of this study is to explore the formation mechanism of tourists' environmental friendly behavior in ecotourism destinations. This information can provide new insights for decision-makers and practitioners to design or adjust schemes related to reducing pollution and implementing ecotourism in protected areas. Based on this and the discussed existing literature, the key themes, hypotheses, and their linkages are represented schematically in Figure 1.

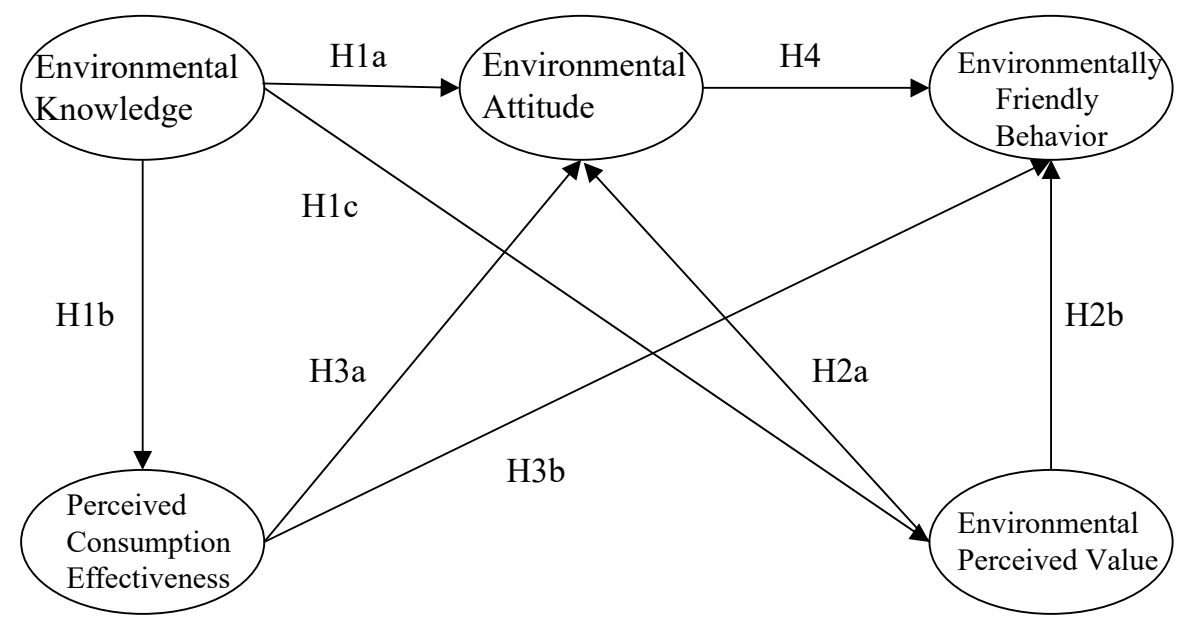

Figure 1. Research model themes and hypotheses (refer to the main text for hypotheses statements $\mathrm{H} 1-\mathrm{H} 4)$.

\section{Materials and Methods}

\subsection{Study Area}

The Shaanxi Taibai Mountain National Nature Reserve is located in the Qinling Mountains at the junction of Taibai, Meixian, and Zhouzhi Counties in Shaanxi Province $\left(107^{\circ} 2225^{\prime \prime}-107^{\circ} 5130^{\prime \prime} \mathrm{E}\right.$ longitude and $33^{\circ} 49^{\prime} 30^{\prime \prime}-34^{\circ} 05^{\prime} 35^{\prime \prime} \mathrm{N}$ latitude) and covers an area of 56,325 ha. The main protection targets are forest ecosystems and natural historical relics. As the main peak of the Qinling Mountains, Taibai Mountain reaches $3767 \mathrm{~m}$ above sea level and marks the intersection of North China, Central China, and the Qinghai-Tibet Plateau. The reserve is rich in animal and plant resources, with distinct vertical vegetation zoning. The forest area is 45,725 ha $(81.2 \%$ cover), and the total forest stock is 7.05 million $\mathrm{m}^{3}$. The flora of Taibai Mountain is not only transitional, but also ecologically unique, acting as an important distribution center and origin of endemic plants in China (Figure 2).

Due to its beautiful natural landscape and valuable ecological environment, the Taibai Mountain National Nature Reserve attracts an increasing number of tourists for recreation and vacations. With this influx of tourists, environmentally unfriendly behaviors have been noted, including picking flowers, digging bamboo shoots, and littering, to the detriment of the reserve, with some endemic plant species close to extinction. Therefore, exploring the formation of environmentally friendly tourist behaviors in this location has important practical significance for conservation management.

\subsection{Questionnaire Design}

The questionnaire consisted of two parts. The first part covered the basic demographic information of the respondents, including gender, age, education level, current work industry, and personal monthly income. The second part aimed to record the environmental knowledge, environmental perceived value, perceived consumption effectiveness, environmental attitude, and environmentally friendly behaviors of the respondents by asking them to respond to a range of environmental statements. Existing approaches from the literature were applied with some minor modifications according to the research context and specific 
study area. Among them, the environmental knowledge test scale refers to Haron et al. [89], which is composed of three observation variables; the environmental perceived value scale refers to Sweeney et al. [90], which contains three observation variables; the scale of perceived consumption effectiveness refers to Han et al. [91], including nine observation variables; the environmental attitude scale adopts the new environmental paradigm scale designed by Dunlap et al. [92], including three aspects of human's views on environmental limit, ecological balance, and the relationship between human and nature, with a total of five observation variables; The Environmentally Friendly Behavior Test Scale draws lessons from Lee and Jan [93], Lee et al. [94], and Xiao and Hong [95]. To ensure the applicability of the test scales, three experts and seven doctoral students in related research fields were invited to discuss the measurement variables (statements), which were adjusted where appropriate to ensure they could be easily read and understood by the respondents. The second part of the test scale adopted a five-point Likert scale with responses ranging from "strongly disagree" (1) to "strongly agree" (5). The finalized questionnaire consisted of five potential variables and 26 observed variables (Table 1).

Table 1. Questionnaire items and variables considered.

\begin{tabular}{|c|c|c|}
\hline Latent Variables & Items & Observed Variables \\
\hline \multirow{3}{*}{$\begin{array}{l}\text { Environmental knowledge } \\
\text { (EK) }\end{array}$} & EK1 & Acid rain refers to the acid precipitation caused by air pollution \\
\hline & EK2 & $\begin{array}{l}\text { The destruction of ecosystem balance is caused by both natural and } \\
\text { human factors }\end{array}$ \\
\hline & EK3 & $\begin{array}{l}\text { Among waste paper, waste glass, and waste batteries, waste batteries are } \\
\text { most harmful to the environment }\end{array}$ \\
\hline \multirow{6}{*}{$\begin{array}{c}\text { Environmental perceived } \\
\text { value }(\mathrm{EPV})\end{array}$} & EPV1 & The quality of the tour is good \\
\hline & EPV2 & The tour made me feel good \\
\hline & EPV3 & The tour is worth the money \\
\hline & PCE1 & Individual behavior can play a significant role in environmental protection \\
\hline & PCE2 & $\begin{array}{l}\text { When traveling, I consider the impact of my behavior on the environment } \\
\text { and other tourists }\end{array}$ \\
\hline & PCE3 & $\begin{array}{l}\text { If every tourist protects the environment, we can bring positive influence } \\
\text { to the environment }\end{array}$ \\
\hline \multirow{8}{*}{$\begin{array}{l}\text { Perceived consumption } \\
\text { effectiveness (PCE) }\end{array}$} & PCE4 & I think environmental protection is very important \\
\hline & PCE5 & I am willing to pay extra money for environmental protection \\
\hline & PCE6 & I have an obligation to save resources and protect the environment \\
\hline & PCE7 & $\begin{array}{l}\text { I am willing to contribute to saving resources and protecting } \\
\text { the environment }\end{array}$ \\
\hline & PCE8 & $\begin{array}{l}\text { Supporting the work of nature reserves is conducive to improving the } \\
\text { natural environment }\end{array}$ \\
\hline & PCE9 & $\begin{array}{l}\text { I have a responsibility to actively participate in environmental } \\
\text { protection activities }\end{array}$ \\
\hline & EA1 & We are approaching the limit of population that the earth can bear \\
\hline & EA2 & $\begin{array}{l}\text { When human beings interfere in nature, it often has } \\
\text { disastrous consequences }\end{array}$ \\
\hline \multirow[t]{5}{*}{ Environmental attitude (EA) } & EA3 & Human beings are abusing resources and destroying the environment \\
\hline & EA4 & Human beings are facing a serious "ecological crisis" \\
\hline & EA5 & $\begin{array}{l}\text { According to the current development trend, we will soon experience a } \\
\text { major ecological disaster }\end{array}$ \\
\hline & EFB1 & During the visit, I have obeyed all related laws and regulations. \\
\hline & EFB2 & $\begin{array}{l}\text { During the visit, I have NOT taken away any rock, fossil or mineral, pick } \\
\text { up plants or their fruit. }\end{array}$ \\
\hline \multirow{4}{*}{$\begin{array}{c}\text { Environmentally friendly } \\
\text { behaviors (EFB) }\end{array}$} & EFB3 & $\begin{array}{l}\text { I have stayed on marked paths designated by the scenic spot and have not } \\
\text { entered the restricted. }\end{array}$ \\
\hline & EFB4 & $\begin{array}{l}\text { I have actively payed attention to environmental protection and } \\
\text { information during the visit. }\end{array}$ \\
\hline & EFB5 & I have taken public transport (low-carbon transport) to the scenic spot. \\
\hline & EFB6 & $\begin{array}{l}\text { During the visit, I have been recycling, such as sorting, saving, or } \\
\text { reusing trash. }\end{array}$ \\
\hline
\end{tabular}




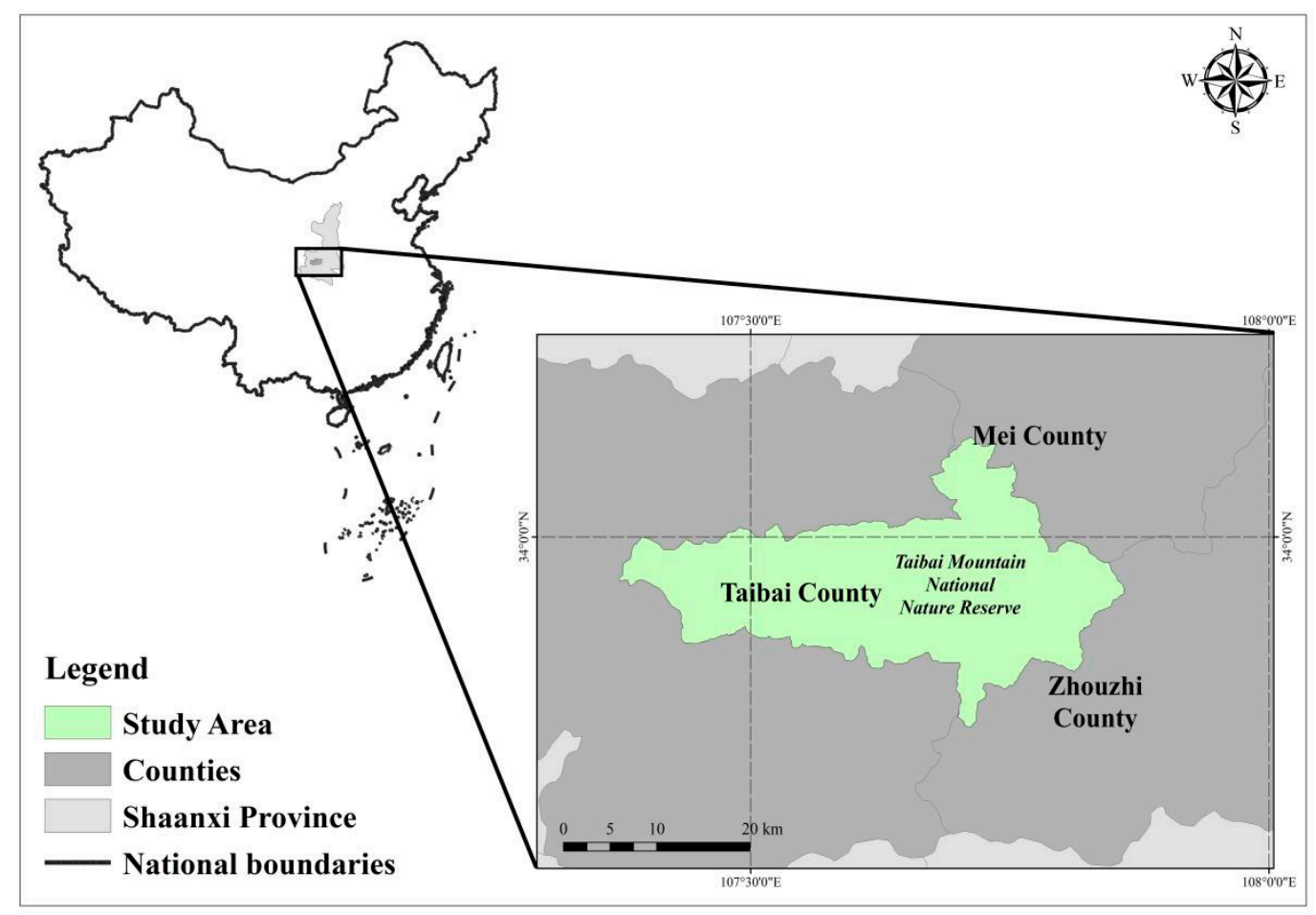

Figure 2. Map of study area.

\subsection{Data Collection}

The survey data were collected in July 2018, which is the peak season of local tourism. Before the formal investigation, the research team conducted a preliminary investigation in March 2018. Through communication with the local ecological protection department and tourism authorities, the area and route of data collection were determined, and the initial questionnaire was trialed in the study area to ensure that it could be understood by the respondents. Before asking questions, the research team explained the survey objectives and questions to the respondents to minimize potential misunderstandings. After the respondents completed the survey, they would receive thank you gifts, such as souvenirs. According to the preliminary survey results, with the help of the investigators, more than $95 \%$ of the tourists were able to complete all of the questions. According to the survey results, the research team adjusted and optimized the survey plan and officially launched the main survey in 2018. The questionnaires were distributed by random interception. The data collection team consisted of 9 graduate students from Beijing Forestry University, all of whom were trained social science researchers with previous experience in tourism surveys. Overall, a total of 450 questionnaires were distributed and 430 were recovered, of which 406 were valid giving a final questionnaire efficiency of $94 \%$.

A descriptive statistical analysis of the recovered valid questionnaires in Table 2 shows the general composition of the respondents. The proportion of male and female tourists was balanced, with $30-39$ year-olds (36.45\%) and $20-29$ year-olds $(24.88 \%)$ making up the largest groups; most respondents had a Bachelor's degree (43.10\%); most were employed in the science, education, culture, and health $(22.91 \%)$, and the industry, manufacturing, and construction (21.18\%) sectors; and the dominant monthly income groups were $4000-6000$ yuan $(33.25 \%)$ and $2000-4000$ yuan $(28.57 \%)$. 
Table 2. Demographic characteristics of the tourist sample $(n=406)$.

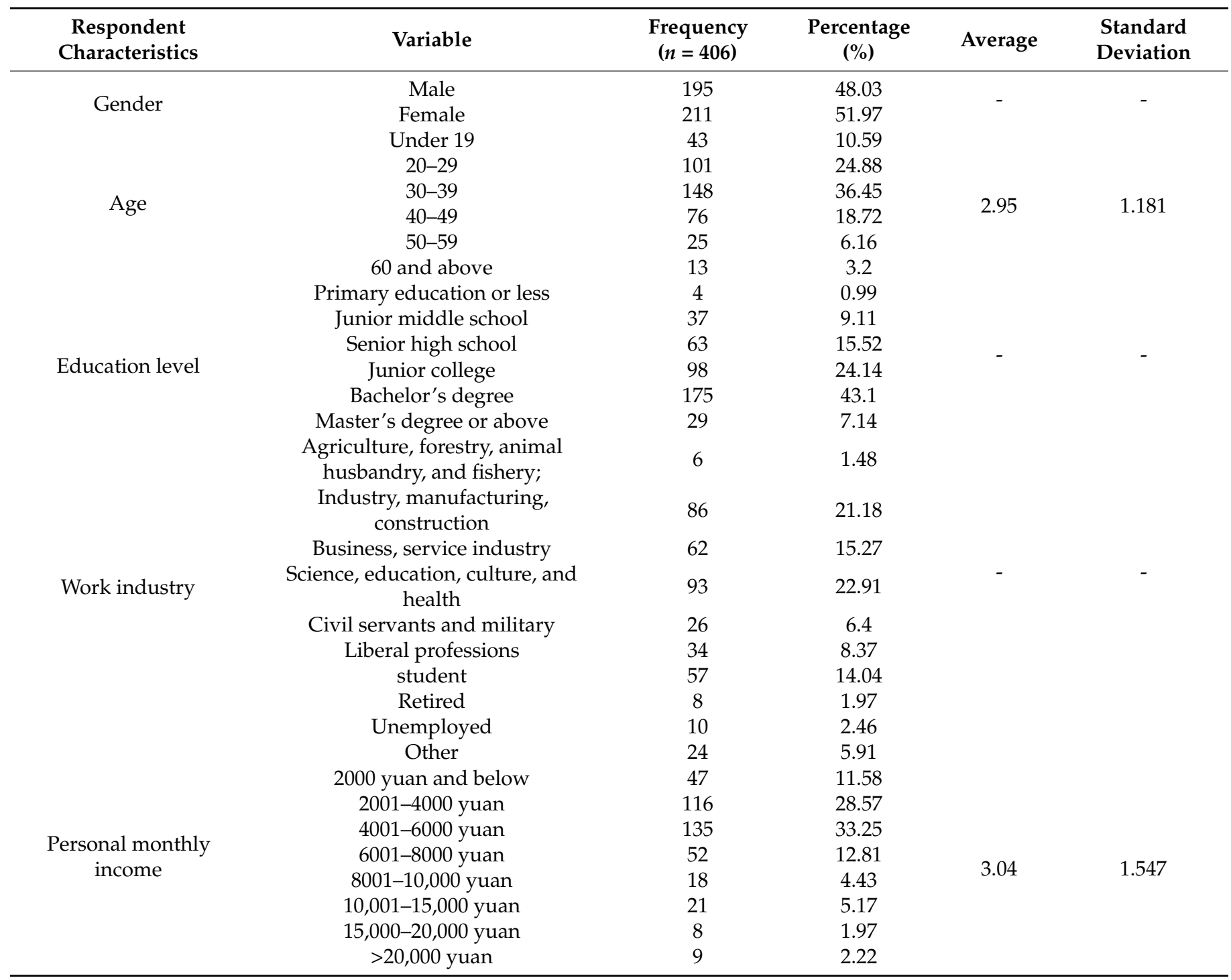

\subsection{Statistical Analysis}

Given the inclusion of many latent variables and the nature of the hypotheses investigated, the structural equation model offered a suitable means of analysis. This was applied using SPSS (Version 22.0, IBM Corporation, New York, NY, USA) and Amos (Version 24.0, IBM Corporation, New York, NY, USA) statistical software. Anderson and Gerbing's [96] method was adopted to test the model using a two-step strategy. First, the measurement model was verified through confirmatory factor analysis (CFA), which examines the goodness-of-fit of the model, aggregation validity, and discriminative validity of each latent variable, and the relationship between each observed variable and latent variable was determined. Second, the fitting coefficients and path coefficients of the hypothetical model were measured through structural equation modeling.

\section{Results}

\subsection{Model Fit Tests}

An appropriate measurement model evaluation is a prerequisite for structural model evaluation. Before the integrated structural model analysis, confirmatory factor analysis (CFA) was used to analyze the structure and influence relationships of the potential variables. The data were imported into Amos 24.0 statistical software to build a measurement 
model, including the five potential variables (i.e., environmental knowledge, environmental attitude, environmental perceived value, perceived consumption effectiveness, and environmentally friendly behavior) and test the validity of each measurement index and the discriminant validity between the potential variables.

\subsection{Reliability Test}

Cronbach's $\alpha$ (alpha) and the combined reliability of the latent variables were used to judge the test reliability, as widely applied elsewhere. Generally, Cronbach's $\alpha \geq 0.70$ indicates that a questionnaire has high reliability; $0.35 \leq$ Cronbach's $\alpha<0.70$ indicates a questionnaire offers generally good reliability; and Cronbach's $\alpha<0.35$ indicates a questionnaire has low reliability. When the combined reliability is greater than 0.7 , the fitness of the model is good. As shown in Table 3, the combined reliability of each latent variable was $0.773-0.948$, and the Cronbach's $\alpha$ values range between 0.757 and 0.944 , indicating high reliability.

Table 3. Internal and convergent reliability. AVE: Average variance extracted.

\begin{tabular}{|c|c|c|c|c|c|c|c|c|c|c|}
\hline Latent Variables & $\begin{array}{c}\text { Observed } \\
\text { Variable }\end{array}$ & UNSTD. & S.E. & $\begin{array}{c}t- \\
\text { Value }\end{array}$ & $p$ & STD. & SMC & CR & AVE & $\begin{array}{c}\text { Cronbach's } \\
\alpha\end{array}$ \\
\hline \multirow{3}{*}{$\begin{array}{l}\text { Environmental } \\
\text { knowledge (EK) }\end{array}$} & EK1 & 1.000 & & & & 0.758 & 0.575 & \multirow{3}{*}{0.818} & \multirow{3}{*}{0.600} & \multirow{3}{*}{0.813} \\
\hline & EK2 & 1.019 & 0.076 & 13.482 & $* * *$ & 0.838 & 0.702 & & & \\
\hline & EK3 & 1.017 & 0.078 & 13.113 & $* * *$ & 0.723 & 0.523 & & & \\
\hline \multirow{6}{*}{$\begin{array}{l}\text { Environmental } \\
\text { perceived value } \\
(\mathrm{EPV})\end{array}$} & EPV1 & 1.000 & & & & 0.806 & 0.650 & \multirow{3}{*}{0.773} & \multirow{3}{*}{0.535} & \multirow{3}{*}{0.757} \\
\hline & EPV2 & 0.867 & 0.079 & 10.971 & $* * *$ & 0.746 & 0.557 & & & \\
\hline & EPV3 & 0.969 & 0.093 & 10.468 & $* * *$ & 0.630 & 0.397 & & & \\
\hline & PCE1 & 1.000 & & & & 0.822 & 0.676 & \multirow{10}{*}{0.948} & \multirow{10}{*}{0.670} & \multirow{10}{*}{0.944} \\
\hline & PCE2 & 0.531 & 0.031 & 16.963 & $* * *$ & 0.735 & 0.540 & & & \\
\hline & PCE3 & 1.118 & 0.055 & 20.404 & $* * *$ & 0.835 & 0.697 & & & \\
\hline \multirow{7}{*}{$\begin{array}{c}\text { Perceived } \\
\text { consumption } \\
\text { effectiveness (PCE) }\end{array}$} & PCE4 & 0.900 & 0.054 & 16.560 & $* * *$ & 0.722 & 0.521 & & & \\
\hline & PCE5 & 0.910 & 0.046 & 19.744 & $* * *$ & 0.817 & 0.667 & & & \\
\hline & PCE6 & 0.855 & 0.040 & 21.455 & $* * *$ & 0.862 & 0.743 & & & \\
\hline & PCE7 & 0.914 & 0.040 & 22.736 & $* * *$ & 0.893 & 0.797 & & & \\
\hline & PCE8 & 1.036 & 0.048 & 21.753 & $* * *$ & 0.869 & 0.755 & & & \\
\hline & PCE9 & 1.002 & 0.053 & 19.082 & $* * *$ & 0.799 & 0.638 & & & \\
\hline & EA1 & 1.000 & & & & 0.641 & 0.411 & & & \\
\hline \multirow{3}{*}{$\begin{array}{l}\text { Environmental } \\
\text { attitude (EA) }\end{array}$} & EA2 & 1.302 & 0.099 & 13.094 & $* * *$ & 0.766 & 0.587 & \multirow{4}{*}{0.895} & \multirow{4}{*}{0.634} & \multirow{3}{*}{0.889} \\
\hline & EA3 & 1.457 & 0.100 & 14.607 & $* * *$ & 0.890 & 0.792 & & & \\
\hline & EA4 & 1.604 & 0.109 & 14.735 & $* * *$ & 0.903 & 0.815 & & & \\
\hline \multirow{7}{*}{$\begin{array}{l}\text { Environmentally } \\
\text { friendly behavior } \\
\text { (EFB) }\end{array}$} & EA5 & 1.583 & 0.122 & 12.926 & $* * *$ & 0.753 & 0.567 & & & \multirow{7}{*}{0.894} \\
\hline & EFB1 & 1.000 & & & & 0.839 & 0.704 & \multirow{6}{*}{0.900} & \multirow{6}{*}{0.605} & \\
\hline & EFB2 & 1.102 & 0.053 & 20.736 & $* * *$ & 0.847 & 0.717 & & & \\
\hline & EFB3 & 1.268 & 0.078 & 16.192 & $* * *$ & 0.715 & 0.511 & & & \\
\hline & EFB4 & 1.335 & 0.060 & 22.164 & $* * *$ & 0.886 & 0.785 & & & \\
\hline & EFB5 & 0.975 & 0.062 & 15.679 & $* * *$ & 0.698 & 0.487 & & & \\
\hline & EFB6 & 0.973 & 0.068 & 14.254 & $* * *$ & 0.650 & 0.423 & & & \\
\hline
\end{tabular}

$* * * p<0.001$.

\subsection{Convergent Validity}

Convergent validity was determined using standardized factor loading, $t$-values, and the significance level of each observation variable, as well as the average extraction variance of each latent variable. The discriminant criteria were as follows: Standardized factor loading was $0.50-0.95, t$-values were large, the significance level was $p=0.001$, and the convergent validity was considered good when the average variance extracted (AVE) value was greater than 0.5. According to the results in Table 3, the standardized factor loading distribution of each observation variable was within the range $0.630-0.903$, the $\mathrm{t}$-value distribution ranged 10.468-22.736, which was significant in all cases $(p<0.001)$, and the AVE values ranged between 0.535 and 0.670 , including that the convergent validity of each latent variable was good. 


\subsection{Discriminant Validity}

A discriminant validity measure is used to verify whether there are significant differences between two latent variables of different dimensions. Typically, when the square root of the average variance extracted value of each latent variable is greater than the corresponding square of the correlation coefficient, the observed variable has better discriminant validity [97]. According to Table 4, with the exception of the square of the correlation coefficient between environmental knowledge and environmentally friendly behavior (0.791) is slightly larger than the square root of the average variance extracted value of environmental knowledge (0.775) and the square root of the average variance extracted value of environmentally friendly behaviors (0.778), the squares of the correlation coefficients between the other potential variables are less than the corresponding average variance extracted values. Thus, the discriminant validity of each latent variable was considered to be good overall.

Table 4. Squared correlation coefficients and average variance.

\begin{tabular}{cccccc}
\hline & $\begin{array}{c}\text { Environmentally } \\
\text { Friendly } \\
\text { Behaviors (EFB) }\end{array}$ & $\begin{array}{c}\text { Environmental } \\
\text { Perceived Value } \\
\text { (EPV) }\end{array}$ & $\begin{array}{c}\text { Perceived Consumption } \\
\text { Effectiveness } \\
\text { (PCE) }\end{array}$ & $\begin{array}{c}\text { Environmental } \\
\text { Knowledge } \\
\text { (EK) }\end{array}$ & $\begin{array}{c}\text { Environmental } \\
\text { Attitudes } \\
\text { (EA) }\end{array}$ \\
\hline EFB & $\mathbf{0 . 7 7 8}$ & & & & \\
EPV & 0.261 & $\mathbf{0 . 7 3 1}$ & & & \\
PCE & 0.644 & 0.142 & $\mathbf{0 . 8 1 9}$ & $\mathbf{0 . 7 7 5}$ & \\
EK & 0.791 & 0.177 & 0.564 & 0.382 & $\mathbf{0 . 7 9 6}$ \\
EA & 0.390 & 0.253 & 0.265 & \\
\hline
\end{tabular}

Note: The square roots of AVEs were the bold elements.

\subsection{Structural Model and Hypothesis Testing}

Based on the favorable test results for reliability, convergent validity, and discriminant validity of the relationship model, the maximum likelihood method was used to estimate the parameters of the model, with a $\chi^{2} / \mathrm{DF}$ value of 2.482 and a RMSEA value of 0.060 (see Table 5). The absolute fitness index, value-added fitness index, and simplified fitness index of the model were, therefore, in line with the evaluation standard, indicating the good overall fitting validity of the final model.

Table 5. Results of model fitness test $(n=406)$.

\begin{tabular}{cccccccccccc}
\hline \multirow{2}{*}{ Fitness Index } & \multicolumn{4}{c}{ Absolute Fitness Index } & \multicolumn{2}{c}{ Value-Added Fitness Index } & \multicolumn{4}{c}{ Simplified Fitness Index } \\
\cline { 2 - 12 } & RMSEA & RMR & GFI & AGFI & NFI & CFI & IFI & PGFI & PNFI & PCFI \\
\hline Evaluation & $<0.7$ & $<0.7$ & $>0.9$ & $>0.8$ & $>0.9$ & $>0.9$ & $>0.9$ & $>0.5$ & $>0.5$ & $>0.5$ \\
standard & 0.060 & 0.061 & 0.925 & 0.897 & 0.922 & 0.952 & 0.952 & 0.671 & 0.753 & 0.777 \\
Fitting value & YES & YES & YES & YES & YES & YES & YES & YES & YES & YES \\
Judgment & & & & & & & & &
\end{tabular}

The model show that environmental knowledge has a significant positive relationship with environmental attitude, perceived consumption effectiveness, and environmental perceived value; environmental perceived value has a significant positive relationship with environmental attitudes and environmentally friendly behavior; perceived consumption effectiveness is positively correlated with environmental attitude, but not significantly; perceived consumption effectiveness is significantly positively correlated with environmentally friendly behavior; and environmental attitude is significantly positively correlated with environmentally friendly behavior (Figure 3). Based on these findings, all of the proposed hypotheses (see Section 2) were confirmed with the exception of H3a (Table 6). 


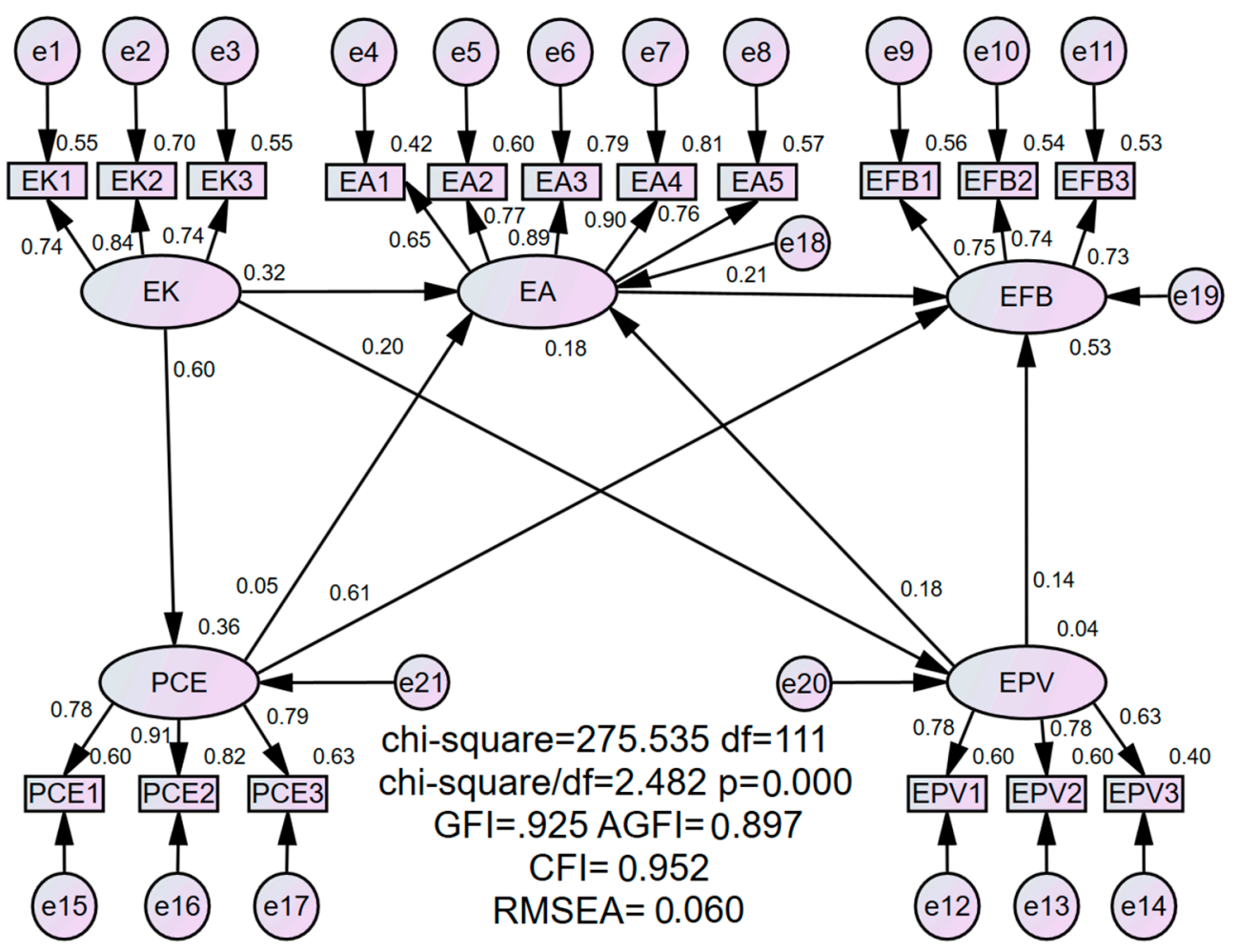

Figure 3. Structural equation model of the constructed theoretical model.

Table 6. Results of hypotheses testing using the modified model.

\begin{tabular}{|c|c|c|c|c|c|c|}
\hline Hypothesis & Path & $\begin{array}{l}\text { Standardized } \\
\text { Factor Loading }\end{array}$ & $t$-Value & $p$ & $\begin{array}{l}\text { Standard } \\
\text { Error }\end{array}$ & Result \\
\hline H1a & $\mathrm{EK} \rightarrow \mathrm{EA}$ & 0.322 & 4.191 & $* * *$ & 0.050 & Supported \\
\hline $\mathrm{H} 1 \mathrm{~b}$ & $\mathrm{EK} \rightarrow \mathrm{PCE}$ & 0.598 & 9.453 & $* * *$ & 0.080 & Supported \\
\hline $\mathrm{H} 1 \mathrm{c}$ & $\mathrm{EK} \rightarrow \mathrm{EPV}$ & 0.201 & 3.252 & $* *$ & 0.041 & Supported \\
\hline $\mathrm{H} 2 \mathrm{a}$ & $\mathrm{EPV} \rightarrow \mathrm{EA}$ & 0.181 & 3.094 & $* *$ & 0.053 & Supported \\
\hline $\mathrm{H} 2 \mathrm{~b}$ & $\mathrm{EPV} \rightarrow \mathrm{EFB}$ & 0.138 & 2.444 & * & 0.078 & Supported \\
\hline H3a & $\mathrm{PCE} \rightarrow \mathrm{EA}$ & 0.048 & 0.697 & 0.486 & 0.035 & Unsupported \\
\hline $\mathrm{H} 3 \mathrm{~b}$ & $\mathrm{PCE} \rightarrow \mathrm{EFB}$ & 0.607 & 9.372 & $* * *$ & 0.047 & Supported \\
\hline $\mathrm{H} 4$ & $\mathrm{EA} \rightarrow \mathrm{EFB}$ & 0.206 & 3.876 & $* * *$ & 0.080 & Supported \\
\hline
\end{tabular}

\section{Discussion}

Research on environmentally friendly behaviors has mainly focused on the United States, Canada, Spain, Portugal, and other developed countries [98-100]. In recent years, although relevant research has also been carried out in India, Ghana, and other developing countries, there are few studies focusing on ecotourism destinations in China [101]. Here, focusing on the Shaanxi Taibai Mountain National Nature Reserve, the environmental knowledge, environmental attitude, environmental perception value, and perceived consumption effectiveness of tourists were examined as influencers of pro-environmental behavior.

Among the four explanatory variables, the total effect of perceived consumption effectiveness on environmentally friendly behavior was the strongest (standardized total impact coefficient $=0.617$ ), followed by environmental knowledge $(0.471)$ and environmental attitude (0.206); the total effect of environmental perceived value on environmentally friendly behavior was the weakest (0.175). This shows that tourist behaviors can have an impact on the ecological environment of the tourism destination. The results imply that environmental knowledge has a significant positive impact on environmental attitudes, perceived consumption effectiveness, and perceived value. Thus, H1a, H1b, and H1c are supported. This is consistent with the results of Zsóka et al. [102], who suggest that 
people with more environmental knowledge are more likely to hold a positive attitude toward the environment. Indeed, access to knowledge about the environment enables tourists to realize the importance and necessity of the environment to their lives and, as a consequence, are more willing to take active measures to avoid causing damage and participate in protection activities; such activities are associated with improved sensory experiences and psychological well-being [103-105].

Environmental perceived value was also found to have a significant positive impact on attitudes toward the environment and environmentally friendly behaviors ( $\mathrm{H} 2 \mathrm{a}$ and $\mathrm{H} 2 \mathrm{~b}$ ). This is consistent with previous studies showing that tourists with higher environmental perception value are less likely to favor their own interests over environmental benefits $[104,106]$. For example, based on a survey of 600 respondents in Australia, Chowdhury and Fernando [107] also identified a positive relationship between environmental perceived value and environmental attitudes; the more tourists appreciate environmental utility, the more conscious they are of the environmental impacts of their own behaviors. Zhang et al. [108] also examined how perceived value affects the environmental responsibility behaviors of tourists, finding that environmental, service, characteristic, knowledge and education, management, and cost values all have significant impacts on behavior. In their study of consumers' green purchasing behavior, Chan and Lau [109] also found that perceived value was the most important predictor alongside perceived product effectiveness and usability.

In line with planned behavior theory, environmental attitude was also identified as a significant factor influencing environmentally friendly behaviors (H4). The more tourists appreciate an aesthetically beautiful natural environment, the more conscious they are of environmentally friendly behaviors. Similar relationships have been observed through the study of college students' active recycling habits [110], and Chen and Zhang [111] further support planned behavior theory in the context of consumer attitudes toward the purchase of hydrogen-fueled vehicles. In the context of tourism, Tanner and Kast [112] showed that an individual's attitude is an important determinant of environmentally friendly behavior, and Yadav and Pathak [113] found that changing environmental perceived value, environmental attitude, and intrinsic behavioral motivation were critical for producing pro-environmental behaviors. Furthermore, Vermeir and Verbek [114] suggested that a positive attitude toward the environment can also affect consumers' green consumption behavior. Importantly, wider participation in ecotourism has the potential to significantly improve the environmental awareness and attitudes of tourists, fostering environmentally friendly behaviors.

Finally, perceived consumption effectiveness was identified as an important (positive) factor influencing environmentally friendly behavior at the studied protected area (influence path coefficient $r=0.607, p<0.001 ; \mathrm{H} 3 \mathrm{~b}$ ), as suggested elsewhere [115,116]. In previous studies, perceived consumption effectiveness is considered to have a relatively weak effect on environmentally friendly behavior $[66,67]$. Thus, individuals may attach great importance to nature and the environment without believing they have any great effect on it. This disparity is associated with the belief that environmental problems cannot be alleviated through individual actions, thus denying or replacing individual environmental responsibility [117-119]. In contrast to the findings of this study, Huang et al. [39] found that perceived consumption effectiveness, as mediated by environmental attitude, has only an indirect impact on environmentally friendly behaviors and a weaker impact than other observed variables. Importantly, the development of ecotourism in nature reserves is based on practical experiences that ecotourism has the potential to promote ecological conservation. As specific actions lead to environmental reactions, the decision making and behavior of tourists participating in ecotourism are critical for achieving the conservation goals and sustainable development of ecotourism destinations. Therefore, compared with traditional forms of tourism, ecotourists likely have higher environmental sensitivity and stronger positive environmental attitudes. As such, while the effect of perceived consumption effectiveness on environmental attitude was not found to be significant, they 
were positively correlated. In addition, a large number of studies in cognitive psychology suggest that people are overconfident in their own knowledge [120,121], and tend to have unrealistic optimism about future events [122]. Therefore, the responses of the tourists at the study site represent an overall overestimation of their abilities to transform the natural environment, which may further explain the observed trends.

\section{Conclusions}

The factors influencing environmentally friendly behaviors were examined using a questionnaire-based survey of 406 tourists at the Taibai Mountain National Nature Reserve in China. Based on structural equation modeling, tourist perceived consumption effectiveness, environmental perceived value, and environmental attitude had significant positive effects on environmentally friendly behaviors. While environmental knowledge had a positive but non-significant effect positive impact on environmentally friendly behavior, it had significant impacts on environmental perceived value, perceived consumption effectiveness, and environmental attitude. Perceived consumption effectiveness had the strongest overall impact on environmentally friendly behavior.

In the more fragile and broken ecological environment of protected areas, human behavior is the root of environmental problems. Identifying those mechanisms that can promote sustainable development and environmentally friendly behaviors is a key component of agendas aimed at addressing ecological damage at ecotourism destinations. We believe that these findings not only provide supporting information for promoting environmentally friendly tourist behaviors toward protected areas, but also provide new methods and a strong theoretical basis for the implementation of nature education programs. Based on this, we suggest that, first of all, policy makers can use propaganda means to improve tourists' awareness and perception of environmental damage, and improve tourists' environmental knowledge and environmental perception value by carrying out environmental knowledge lectures. Secondly, the perceived consumption effectiveness and environmental attitude can be stimulated by non-formal educations, such as watching environmental protection movies and visiting protected areas, so as to enhance the relevance between individuals and the environment, so that the perceived consumption effectiveness of individuals can effectively stimulate the generation of environmental behavior. Finally, some natural experience projects adapted to local conditions could be set up in ecotourism destinations alongside the provision of tourist information to explain the unique environmental resources and ecological values of such destinations. This should enhance the association between individuals and the environment, strengthening perceived consumption effectiveness and, therefore, environmentally friendly behaviors.

The limitations of the study should be noted. First, as a self-reporting method was used for the questionnaire survey, a certain degree of social expectation and recall bias was inevitable. Second, the theory of planned behavior applied to the research has some limitations in the context of the study, as subjective norms and perceived behavioral intentions were not included in the model. To address this, a more complete theoretical model of planned behavior could be applied in future research. Third, the sampling was subject to some geographical restrictions, and future comparisons with other reserves and other types of ecotourism destinations would be beneficial. Finally, the complexities of tourist behaviors at ecotourism destinations cannot be fully captured using structural equation modeling. Therefore, on-going research on the factors driving environmentally friendly tourist behaviors should continue to supplement and improve the findings presented here.

Author Contributions: Conceptualization, J.R. and Y.W.; methodology, J.R. and Y.C.; investigation, J.R. and K.S.; writing-original draft preparation, J.R.; writing—review and editing, J.R., K.S., and Y.C.; supervision, Y.W. All authors have read and agreed to the published version of the manuscript.

Funding: This study was funded by the National Natural Science Foundation of China [71861147001].

Institutional Review Board Statement: Ethical review and approval were waived for this study, due to in our study, participants were invited to join in the survey voluntarily and anonymously 
without generating ethic issues, and all human studies where non-routine procedures are not used in this study.

Informed Consent Statement: Written informed consent has been obtained from the respondents to publish this paper.

Data Availability Statement: The data presented in this study are available on request from the corresponding author. The data are not publicly available due to privacy.

Conflicts of Interest: The authors declare no conflict of interest.

\section{References}

1. Liu, W.; Vogt, C.A.; Luo, J.; He, G.; Frank, K.A.; Liu, J. Drivers and socioeconomic impacts of tourism participation in protected areas. PLoS ONE 2012, 7, e35420. [CrossRef]

2. Ruhanen, L. The prominence of eco in ecotourism experiences: An analysis of post-purchase online reviews. J. Hosp. Tour. Manag. 2019, 39, 110-116. [CrossRef]

3. Diamantis, D. The concept of ecotourism: Evolution and trends. Curr. Issues Tour. 1999, 2, 93-122. [CrossRef]

4. Johannesen, A.; Skonhoft, A. Tourism, poaching and wildlife conservation: What can integrated conservation and development projects accomplish? Resour. Energy Econ. 2004, 27, 208-226. [CrossRef]

5. Ma, B.; Yin, R.S.; Zheng, J.; Wen, Y.L.; Hou, Y.L. Estimating the social and ecological impact of community-based ecotourism in giant panda habitats. J. Environ. Manag. 2019, 250, 31499468. [CrossRef] [PubMed]

6. Cary, J.; Williams, K. Landscape preferences, ecological quality, and biodiversity protection. Environ. Behav. 2002, 34, 257-274. [CrossRef]

7. Choi, Y.E.; Oh, C.-O.; Chon, J. Applying the resilience principles for sustainable ecotourism development: A case study of the Nakdong Estuary, South Korea. Tour. Manag. 2021, 83, 104237. [CrossRef]

8. Chung, M.G.; Pan, T.; Zou, X.; Liu, J. Complex interrelationships between ecosystem services supply and tourism demand: General framework and evidence from the origin of Three Asian Rivers. Sustainability 2018, 10, 4576. [CrossRef]

9. Bossley, J.; Smiley, P. Impact of student-induced disturbance on stream macroinvertebrates differs among habitat types. Sci. Rep. 2019, 9, 1447. [CrossRef]

10. Kaffashi, S.; Radam, A.; Shamsudin, M.N.; Yacob, M.R.; Nordin, N.H. Ecological Conservation, Ecotourism, and Sustainable Management: The Case of Penang National Park. Forests 2015, 6, 2345-2370. [CrossRef]

11. Medeiros, H.M.N.; Guerreiro, Q.L.d.M.; Vieira, T.A.; Silva, S.M.S.d.; Renda, A.I.d.S.A.; Oliveira-Junior, J.M.B. Alternative Tourism and Environmental Impacts: Perception of Residents of an Extractive Reserve in the Brazilian Amazonia. Sustainability 2021, 13, 2076. [CrossRef]

12. Das, M.; Chatterjee, B. Ecotourism: A panacea or a predicament? Tour. Manag. Perspect. 2015, 14, 3-16. [CrossRef]

13. Wang, W.Y.; Liu, J.L.; Innes, J.L. Conservation equity for local communities in the process of tourism development in protected areas: A study of Jiuzhaigou Biosphere Reserve, China. World Dev. 2019, 124, 104637. [CrossRef]

14. Dynowski, P.; Senetra, A.; Źróbek-Sokolnik, A.; Kozłowski, J. The Impact of Recreational Activities on Aquatic Vegetation in Alpine Lakes. Water 2019, 11, 173. [CrossRef]

15. Brandt, J.S.; Buckley, R.C. A global systematic review of empirical evidence of ecotourism impacts on forests in biodiversity hotspots. Curr. Opin. Environ. Sustain. 2018, 32, 112-118. [CrossRef]

16. Brandt, J.S.; Kuemmerle, T.; Li, H.M.; Ren, G.P.; Zhu, J.G.; Radeloff, V.C. Using Landsat imagery to map forest change in southwest China in response to the national logging ban and ecotourism development. Remote Sens. Environ. 2012, 121, 358-369. [CrossRef]

17. Mona, M.H.; El-Naggar, H.A.; El-Gayar, E.E.; Masood, M.F.; Mohamed, E.-S.N.E. Effect of human activities on biodiversity in Nabq Protected Area, South Sinai, Egypt. Egypt. J. Aquat. Res. 2019, 45, 33-43. [CrossRef]

18. Noriega, J.A.; Zapata-Prisco, C.; García, H.; Hernández, H.; Hernández, H.; Martínez, R.; Santos-Santos, J.H.; Pablo-Cea, J.D.; Calatayud, J. Does ecotourism impact biodiversity? An assessment using dung beetles (Coleoptera: Scarabaeinae) as bioindicators in a tropical dry forest natural park. Ecol. Indic. 2020, 117, 106580. [CrossRef]

19. Mainieri, T.; Barnett, E.G.; Valdero, T.R.; Unipan, J.B.; Oskamp, S. Green buying: The influence of environmental concern on consumer behavior. J. Soc. Psychol. 1997, 137, 189-204. [CrossRef]

20. Vicente-Molina, M.A.; Fernandez-Sainz, A.; Izagirre-Olaizola, J. Environmental knowledge and other variables affecting proenvironmental behaviour: Comparison of university students from emerging and advanced countries. J. Clean Prod. 2013, 61, 130-138. [CrossRef]

21. Blok, V.; Wesselink, R.; Studynka, O.; Kemp, R. Encouraging sustainability in the workplace: A survey on the pro-environmental behaviour of university employees. J. Clean Prod. 2015, 106, 55-67. [CrossRef]

22. Liu, P.; Teng, M.; Han, C. How does environmental knowledge translate into pro-environmental behaviors? The mediating role of environmental attitudes and behavioral intentions. Sci. Total Environ. 2020, 728, 138126. [CrossRef] [PubMed]

23. Casalo, L.V.; Escario, J.-J. Heterogeneity in the association between environmental attitudes and pro-environmental behavior: A multilevel regression approach. J. Clean Prod. 2018, 175, 155-163. [CrossRef] 
24. Schahn, J.; Holzer, E. Studies of individual environmental concern: The role of knowledge, gender, and background variables. Environ. Behav. 1990, 22, 767-786. [CrossRef]

25. Boerschig, S.; De Young, R. Evaluation of selected recycling curricula: Educating the green citizen. J. Environ. Educ. 1993, 24, 17-22. [CrossRef]

26. Jensen, B.B. Knowledge, action and pro-environmental behaviour. Environ. Educ. Res. 2002, 8, 325-334. [CrossRef]

27. Adomssent, M. Exploring universities' transformative potential for sustainability-bound learning in changing landscapes of knowledge communication. J. Clean Prod. 2013, 49, 11-24. [CrossRef]

28. Laroche, M.; Bergeron, J.; Barbaro-Forleo, G. Targeting Consumers Who Are Willing to Pay More for Environmentally Friendly Products. J. Consum. Mark. 2001, 18, 503-520. [CrossRef]

29. Huang, P.-S.; Shih, L.-H. Effective environmental management through environmental knowledge management. Int. J. Environ. Sci. Technol. 2009, 6, 35-50. [CrossRef]

30. Fahlquist, J.N. Moral responsibility for environmental problems-Individual or institutional? J. Agri. Environ. Ethics 2009, 22, 109-124. [CrossRef]

31. Bamberg, S.; Schmidt, P. Incentives, morality, or habit? Predicting students' car use for university routes with the models of Ajzen, Schwartz, and Triandis. Environ. Behav. 2003, 35, 264-285. [CrossRef]

32. Begum, R.; Chamhuri, S.; Pereira, J.; Jaafar, A. Attitude and behavioral factors in waste management in the construction industry of Malaysia. Resour. Conserv. Recyc. 2009, 53, 321-328. [CrossRef]

33. Maloney, M.P.; Ward, M.P. Ecology: Let's hear from the people: An objective scale for the measurement of ecological attitudes and knowledge. Am. Psychol. 1973, 28, 583. [CrossRef]

34. Ramsey, C.E.; Rickson, R.E. Environmental knowledge and attitudes. J. Environ. Educ. 1976, 8, 10-18. [CrossRef]

35. Barr, S. Factors influencing environmental attitudes and behaviors: A U.K. case study of household waste management. Environ. Behav. 2007, 39, 435-473. [CrossRef]

36. Fan, X.; Huang, J.; Cheng, L. The formation mechanism of residents' environmental friendly behavior in ecotourism areas: A case study of Dongjiang Lake, a national scenic spot. Econ. Geog. 2016, 36, 177-182. (In Chinese)

37. Chen, X.; Peterson, M.N.; Hull, V.; Lu, C.; Lee, G.D.; Hong, D.; Liu, J. Effects of attitudinal and sociodemographic factors on pro-environmental behaviour in urban China. Environ. Conserv. 2011, 38, 45-52. [CrossRef]

38. Duman, T.; Mattila, A. The role of affective factors on perceived cruise vacation value. Tour. Manag. 2005, 26, 311-323. [CrossRef]

39. Huang, J.; Fan, X.; Huang, H. The formation mechanism of tourists' environmental friendly behavior in ecotourism destination-A case study of Mangshan National Nature Reserve. Geog. Res. 2017, 36, 2343-2354. (In Chinese)

40. Thompson, S.C. Will it hurt less if i can control it? A complex answer to a simple question. Psychol. Bull. 1981, 90, 89-101. [CrossRef]

41. Ajzen, I. The theory of planned behavior. Organ. Behav. Hum. Dec. 1991, 50, 179-211. [CrossRef]

42. Ellen, P.; Wiener, J.; Cobb-Walgren, C. The role of perceived consumer effectiveness in motivating environmentally conscious behaviors. J. Pub. Pol. Mark. 1991, 10, 102-117. [CrossRef]

43. Zeithaml, V. Consumer perceptions of price, quality and value: A means-end model and synthesis of evidence. J. Mark. 1988, 52, 2-22. [CrossRef]

44. Morrison, A.M. Hospitality and Travel Marketing; Delmar Cengage Learning: New York, NY, USA, 1996.

45. Stevens, B.F. Price value perceptions of travelers. J. Trav. Res. 1992, 31, 44-48. [CrossRef]

46. Murphy, P.; Pritchard, M.; Smith, J. The destination product and its impact on traveller perceptions. Tour. Manag. 2000, 21, 43-52. [CrossRef]

47. Hutchinson, J.; Lai, F.; Wang, Y. Understanding the relationships of quality, value, equity, satisfaction, and behavioral intentions among golf travelers. Tour. Manag. 2009, 30, 298-308. [CrossRef]

48. Chen, C.-F.; Chen, F.-S. Experience quality, perceived value, satisfaction and behavioral intentions for heritage tourists. Tour. Manag. 2010, 31, 29-35. [CrossRef]

49. Wang, B. An empirical study on the relationship between the image of scenic spots and tourists' perceived value, satisfaction and loyalty. Tour. Sci. 2011, 25, 61-71. (In Chinese)

50. Ruiz-Molina, M.-E.; Gil-Saura, I. Perceived value, customer attitude and loyalty in retailing. J. Retail. Leis. Prop. 2008, 7, 305-314. [CrossRef]

51. Dou, L. Tourists' perceived value, satisfaction and environmental responsibility behavior. J. Arid Land. Resour. Environ. 2016, 30, 197-202. (In Chinese)

52. Fan, J.; Qiu, H.; Wu, X. Destination image, place attachment and tourists' environmental responsibility behavior-A case study of tourist resorts in Zhejiang Province. Tour. Trib. 2014, 29, 55-66. (In Chinese)

53. Chiu, Y.-T.; Lee, W.I.; Chen, T.-H. Environmentally responsible behavior in ecotourism: Antecedents and implications. Tour. Manag. 2014, 40, 321-329. [CrossRef]

54. Xia, Z.; Chen, S. The impact of eco tourists' perceived value on environmental friendly behavior intention. J. Central S. Univ. Forest. Tech. (Soc. Sci.) 2015, 9, 27-32. (In Chinese)

55. Wu, B.; Li, D.; Wang, C. Green or pleasure? The impact of environmental protection activities on consumer behavior. Acta Psychol. Sin. 2016, 48, 1574-1588. (In Chinese) 
56. Snepenger, D.; Murphy, L.; Snepenger, M.; Anderson, W. Normative meanings of experiences for a spectrum of tourism places. J. Travel Res. 2004, 43, 108-117. [CrossRef]

57. Eggert, A.; Ulaga, W. Customer perceived value: A substitute for satisfaction in business markets? J. Bus. Ind. Market. 2002, 17, 107-118. [CrossRef]

58. Kinnear, T.C.; Taylor, J.R.; Ahmed, S.A. Ecologically concerned consumers: Who are they? Ecologically concerned consumers can be identified. J. Market. 1974, 38, 20-24. [CrossRef]

59. Choi, S.; Kim, Y. Antecedents of green purchase behavior: An examination of collectivism, environmental concern, and PCE. Adv. Consum. Res. 2005, 32, 592-599.

60. Straughan, R.; Roberts, J. Environmental segmentation alternatives: A look at green consumer behavior in the new millennium. J. Consum. Mark. 1999, 16, 558-575. [CrossRef]

61. Zhu, J.; Zhou, Y.; Zhang, Y.; Liu, F. Research on the relationship between environmental values and ecological consumption behavior. J. Commerc. Econ. 2019, 76, 39-42. (In Chinese)

62. McDonald, R.; Fielding, K.; Louis, W. Conflicting norms highlight the need for action. Environ. Behav. 2014, 46, 139-162. [CrossRef]

63. Dursun, I.; Kabaday1, E.; Kocak Alan, A.; Tuger, A. Green purchase intention of young Turkish consumers: Effects of consumer's guilt, self-monitoring and perceived consumer effectiveness. Procedia Soc. Behav. Sci. 2015, 207, 165-174.

64. Untaru, E.; Epuran, G.; Ispas, A. A conceptual framework of consumers' pro-environmental attitudes and behaviours in the tourism context. Bull. Transilvania Univ. Brasov Econ. Sci. Ser. V 2014, 7, 85.

65. Kaiser, F.; Gutscher, H. The proposition of a general version of the theory of planned behavior: Predicting ecological behavior. $J$. Appl. Soc. Psychol. 2003, 33, 586-603. [CrossRef]

66. Cho, Y.-N.; Thyroff, A.; Rapert, M.; Park, S.-Y.; Lee, H. To be or not to be green: Exploring individualism and collectivism as antecedents of environmental behavior. J. Bus. Res. 2013, 66, 1052-1059. [CrossRef]

67. Shi, Z.; Wu, L.; Kuang, Z. How can face consciousness reverse selfish behavior? The influence of social value orientation on ecological consumption. J. Market. Sci. 2014, 10, 59-81. (In Chinese)

68. Melnyk, V.; van Herpen, E.; Fischer, A.R.H.; van Trijp, H.C.M. Regulatory fit effects for injunctive versus descriptive social norms: Evidence from the promotion of sustainable products. Market. Lett. 2013, 24, 191-203. [CrossRef]

69. Schultz, P. The structure of environmental concern: Concern for self, other people, and the biosphere. J. Environ. Psychol. 2001, 21, 327-339. [CrossRef]

70. Milfont, T.; Duckitt, J. The environmental attitudes inventory: A valid and reliable measure to assess the structure of environmental attitudes. J. Environ. Psychol. 2010, 30, 80-94. [CrossRef]

71. Olli, E.; Grendstad, G.; Wollebaek, D. Correlates of environmental behaviors: Bringing back social context. Environ. Behav. 2001, 33, 181-208. [CrossRef]

72. Chan, R. Determinants of Chinese consumers' green purchase behavior. Psychol. Mark. 2001, 18, 389-413. [CrossRef]

73. Verbeke, W.; Viaene, J. Consumer attitude to beef quality labeling and associations with beef quality labels. J. Int. Food Agribus. Mark. 1999, 10, 45-65. [CrossRef]

74. Kollmuss, A.; Agyeman, J. Mind the gap: Why do people act environmentally and what are the barriers to pro-environmental behavior? Environ. Educ. Res. 2002, 8, 239-260. [CrossRef]

75. Schlegelmilch, B.; Bohlen, G.; Diamantopoulos, A. The link between green purchasing decisions and measures of environmental consciousness. Eur. J. Mark. 1996, 30, 35-55. [CrossRef]

76. Tilikidou, I. The effects of knowledge and attitudes upon Greeks' pro-environmental purchasing behaviour. Corp. Soc. Respons. Environ. Manag. 2007, 14, 121-134. [CrossRef]

77. Kang, M.; Moscardo, G. Exploring cross-cultural differences in attitudes towards responsible tourist behaviour: A comparison of Korean, British and Australian tourists. Asia Pac. J. Tour. Res. 2006, 11, 303-320. [CrossRef]

78. Perkins, H.E.; Brown, P.R. Environmental values and the so-called true ecotourist. J. Tour. Res. 2012, 51, 793-803. [CrossRef]

79. Ratliff, K.; Howell, J.; Redford, L. Attitudes toward the prototypical environmentalist predict environmentally-friendly behavior. J. Environ. Psychol. 2017, 51. [CrossRef]

80. Hines, J.; Hungerford, H. Analysis and synthesis of research on responsible pro-environmental behavior: A meta-analysis. J. Environ. Educ. 1986, 25, 34-42.

81. Cottrell, S.P.; Graefe, A.R. Testing a conceptual framework of responsible environmental behavior. J. Environ. Educ. 1997, 29, 17-27. [CrossRef]

82. Smith-Sebasto, N.J.; D'Costa, A. Designing a Likert-type scale to predict environmentally responsible behavior in undergraduate students: A multistep process. J. Environ. Educ. 1995, 27, 14-20. [CrossRef]

83. Thapa, B. The mediation effect of outdoor recreation participation on environmental attitude-behavior correspondence. J. Environ. Educ. 2010, 41, 133-150. [CrossRef]

84. Dono, J.; Webb, J.; Richardson, B. The relationship between environmental activism, pro-environmental behaviour and social identity. J. Environ. Psychol. 2010, 30, 178-186. [CrossRef]

85. Iwata, O. Attitudinal determinants of environmentally responsible behavior. Soc. Behav. Person. 2001, 29, 183-190. [CrossRef]

86. Qi, Q.; Zhang, J.; Yang, Y.; Lu, S.; Zhang, H. A study on tourists' environmental attitude and behavior tendency in natural heritage sites-A case study of Jiuzhaigou. Tour. Trib. 2009, 24, 41-46. (In Chinese) 
87. Zhao, Z.; Dong, L.; Wang, X. Research on the relationship between sense of place attachment and environmental behavior-Based on the survey of beach tourists. Sociol. Rev. China 2013, 1, 76-85. (In Chinese)

88. Wang, J.; Li, C.; Tian, M. Classification and evaluation system construction of ecotourism resources. Geog. Res. 2006, 25, 507-516. (In Chinese)

89. Haron, S.; Paim, L.; Yahaya, N. Towards sustainable consumption: An examination of environmental knowledge among Malaysians. Int. J. Consum. Stud. 2005, 29, 426-436. [CrossRef]

90. Sweeney, J.C.; Soutar, G.N. Consumer perceived value: The development of a multiple item scale. J. Retail. 2001, 77, 203-220. [CrossRef]

91. Yoon, H. Hotel customers' environmentally responsible behavioral intention: Impact of key constructs on decision in green consumerism. Int. J. Hosp. Manag. 2015, 45, 22-33. [CrossRef]

92. Dunlap, R.E.; Van Liere, K.D. The "new environmental paradigm". J. Environ. Educ. 1978, 9, 10-19. [CrossRef]

93. Lee, T.H.; Jan, F.-H. The Effects of recreation experience, environmental attitude, and biospheric value on the environmentally responsible behavior of nature-based tourists. Environ. Manag. 2015, 56, 193-208. [CrossRef] [PubMed]

94. Lee, T.H.; Jan, F.-H.; Yang, C.-C. Conceptualizing and measuring environmentally responsible behaviors from the perspective of community-based tourists. Tour. Manag. 2013, 36, 454-468. [CrossRef]

95. Xiao, C.Y.; Hong, D.H. Gender differences in environmental behaviors in China. Popul. Environ. 2010, 32, 88-104. [CrossRef]

96. Anderson, J.C.; Gerbing, W. Structural equation modeling in practice: A review and recommended two-step approach. Psychol. Bull. 1988, 27, 5-24. [CrossRef]

97. Bagozzi, R. Evaluating structural equation models with unobservable variables and measurement error: A comment. J. Mark. Res. 1981, 18, 375. [CrossRef]

98. Paço, A.; Lavrador, T. Environmental knowledge and attitudes and behaviours towards energy consumption. J. Environ. Manag. 2017, 197, 384-392. [CrossRef]

99. Aldieri, L.; Carlucci, F.; Vinci, C.; Yigitcanlar, T. Environmental innovation, knowledge spillovers and policy implications: A systematic review of the economic effects literature. J. Clean Prod. 2019, 239, 118051. [CrossRef]

100. Escario, J.-J.; Rodriguez-Sanchez, C.; Casaló Ariño, L. The influence of environmental attitudes and perceived effectiveness on recycling, reducing, and reusing packaging materials in Spain. Waste Manag. 2020, 113, 251-260. [CrossRef] [PubMed]

101. Gautam, V. Examining environmental friendly behaviors of tourists towards sustainable development. J. Environ. Manag. 2020, 276, 111292. [CrossRef]

102. Zsóka, Á.; Szerényi, Z.; Széchy, A.; Kocsis, T. Greening due to environmental education? Environmental knowledge, attitudes, consumer behavior and everyday pro-environmental activities of Hungarian high school and university students. J. Clean Prod. 2013, 48, 126-138. [CrossRef]

103. Faize, F.A.; Akhtar, M. Addressing environmental knowledge and environmental attitude in undergraduate students through scientific argumentation. J. Clean Prod. 2020, 252, 119928. [CrossRef]

104. van Riper, C.J.; Kyle, G.T.; Sherrouse, B.C.; Bagstad, K.J.; Sutton, S.G. Toward an integrated understanding of perceived biodiversity values and environmental conditions in a national park. Ecol. Indic. 2017, 72, 278-287. [CrossRef]

105. Su, K.; Ren, J.; Qin, Y.; Hou, Y.; Wen, Y. Efforts of indigenous knowledge in forest and wildlife conservation: A case study on Bulang People in Mangba Village in Yunnan Province, China. Forests 2020, 11, 1178. [CrossRef]

106. Wu, B.; Yang, Z. The impact of moral identity on consumers' green consumption tendency: The role of perceived responsibility for environmental damage. J. Environ. Psychol. 2018, 59. [CrossRef]

107. Chowdhury, R.M.; Fernando, M. The relationships of empathy, moral identity and cynicism with consumers' ethical beliefs: The mediating role of moral disengagement. J. Bus. Ethics 2014, 124, 677-694. [CrossRef]

108. Zhang, T.; Liu, J.; Cong, L.; Jia, Y. The impact of perceived value and place attachment on tourists' environmental responsibility behavior: A case study of Beijing Olympic Forest Park. J. Arid Land Resour. Land. 2020, 34, 202-208. (In Chinese)

109. Chan, R.Y.; Lau, L.B. Explaining green purchasing behavior: A cross-cultural study on American and Chinese consumers. J. Int. Consum. Mark. 2002, 14, 9-40. [CrossRef]

110. Wan, C.; Cheung, R.; Shen, G. Recycling attitude and behaviour in university campus: A case study in Hong Kong. Facilities 2012, 30, 630-646. [CrossRef]

111. Chen, M.; Zhang, W.-H. Purchase intention for hydrogen automobile among Chinese citizens: The influence of environmental concern and perceived social value. Int. J. Hydrogen Energy 2020. [CrossRef]

112. Tanner, C.; Kast, S.K. Promoting sustainable consumption: Determinants of green purchases by Swiss consumers. Psychol. Mark. 2003, 20, 883-902. [CrossRef]

113. Yadav, R.; Pathak, G. Young consumers' intention towards buying green products in a developing nation: Extending the theory of planned behavior. J. Clean Prod. 2016, 135, 732-739. [CrossRef]

114. Vermeir, I.; Verbeke, W. Sustainable food consumption: Exploring the consumer "attitude-behavioral intention" gap. J. Agric. Environ. Ethics 2006, 19, 169-194. [CrossRef]

115. Lai, C.; Cheng, E.W.L. Green purchase behavior of undergraduate students in Hong Kong. Soc. Sci. J. 2015, 53. [CrossRef]

116. Laudenslager, M. Understanding air force members' intentions to participate in pro-environmental behaviors: An application of the theory of planned behavior. Percept. Motor Skills 2004, 98, 1162. [CrossRef] 
117. Gössling, S.; Haglund, L.; Kallgren, H.; Revahl, M.; Hultman, J. Swedish air travellers and voluntary carbon offsets: Towards the co-creation of environmental value? Curr. Issues Tour. 2009, 12, 1-19. [CrossRef]

118. Juvan, E.; Dolnicar, S. The attitude-behaviour gap in sustainable tourism. Ann. Tour. Res. 2014, 48, 76-95. [CrossRef]

119. Van der Werff, E.; Steg, L.; Keizer, K. The value of environmental self-identity: The relationship between biospheric values, environmental self-identity and environmental preferences, intentions and behaviour. J. Environ. Psychol. 2013, 34, 55-63. [CrossRef]

120. Heaton, J.B. Managerial optimism and corporate finance. In Advances in Behavioral Finance; Princeton University Press: Princeton, NJ, USA, 2002; pp. 33-45.

121. Griffin, D.; Tversky, A. The weighing of evidence and the determinants of confidence. Cogn. Psychol. 1992, 24, 411-435.

122. Kunda, Z. Motivated inference: Self-serving generation and evaluation of causal theories. J. Person. Soc. Psychol. 1987, 53. [CrossRef] 